\title{
MACHINABILITY OF NANO-STRUCTURED BIOMATERIALS FOR DENTAL IMPLANTS
}

\begin{abstract}
High quality materials are characterized by increased wear resistance, high strength and hardness, abrasive wear resistance, heat and creep resistance. Due to these properties some materials are considered as hard to machine. This group of materials includes biocompatible materials used for manufacturing implants from commercially pure titanium TiGr2, TiGr5, nano-structured commercially pure titanium $n T i$ and volume-formed titanium alloy TiNbTa. Materials were tested by milling operations with different cutting parameters and force of cutting monitoring.
\end{abstract}

Keywords: Biocompatible material, nano-structured titanium, machining.

\section{Introduction}

Biomaterial is a material used in medicine for manufacturing implants, tools and parts for medical devices which are intended to be in physical contact with living tissue. Research and development of both metallic and non-metallic biomaterials enables advances in the field of medicine and especially brings great benefit to those who need it. Problems occur in the life-time of implants, which can be a few years, due to their low chemical conductivity and low stiffness. Therefore, current research is focused on bioinert materials, bioactive materials and materials that are able to be absorbed [1 and 2].

Attempts to mechanically fix artificial teeth in living tissue were first made by the ancient Egyptians around the year 2000 BC, according to Tvrdon [3], and his literary records mention stone-made implants dating from the period before Columbus. At that time, the inhabitants of South America experimented with the replacement of missing teeth using hand-made ivory substitutes or alternatively wooden substitutes.

According to Selingerová [4], the oldest methods of tooth substitution include injecting gold needles into bone tissue as performed by the ancient Chinese. She likewise states that denture development was first recorded in the 18th century. The initial human efforts to replace missing teeth with teeth from another donor were unsuccessful, and had an extremely low success rate. This changed in 1809 with Maggiolo's implant made of gold.

In 1886, Edmund was the first in the United States to test the implantation of a platinum plate into the jaw followed by deployment of a porcelain crown. In 1930 brothers Alvin and
Moses Stock came up with a thread-shaped implant and used Vitallium as a biocompatible Cr-Co-Mo alloy. Certain types of implants used today are still cast from Vitallium. A few years later, the Italian Formigini started a new era of dental implantology by using bioinert tantalum as the implant material. In 1948, a new type of implant, the subperiosteal implant, was developed. The creator was Swedish dentist Gustav Dahl. Independently of Dahl, in 1967 the first razor titanium implant was introduced by New York dentist Leonard I. Linkowom. Rapid expansion of razor implants (Fig. 1) into the practice reached a peak at the end of the 1960s and early 1970s [4].
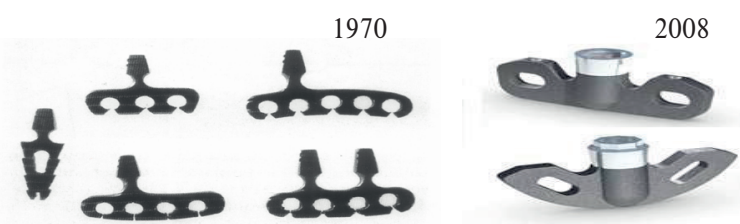

Fig. 1 Blade implant in 1970 and now [4]

So far the most significant breakthrough in the field of dental implantology is the work of Professor Per-Ingvar Branemark. His beginnings date back to 1952 when he discovered the principle of osseointegration, the integration of an implant into bone tissue. According to Simunek [5], Branemark later became the founder of modern dental implantology. He experimented with cylindrical implants made of pure titanium, which showed long-term results.

Currently, dental implants manufactured from commercially pure titanium and titanium alloys do not meet all the needed requirements, so new materials are under development, such as nano-structured titanium which is produced by extrusion of the

\footnotetext{
* Dana Stancekova, Jan Semcer, Jozef Holubjak, Mario Drbul

Department of Applied Mechanics, Faculty of Mechanical Engineering, University of Zilina, Slovakia

E-mail: dana.stancekova@fstroj.uniza.sk
} 
material through a tube with constant diameter, i.e., the use of ECAP technology. Volume-formed TiNbTa alloys are often used too.

\section{Design of dental implants}

Commonly used conventional materials are currently being replaced by materials with better mechanical properties. This group of materials includes high chromium steels, cobalt and nickel alloys, titanium and titanium alloys. Titanium and titanium alloys belong to the group of materials that are hard to machine owing to their good chemical and physical properties like high strength, high corrosion resistance, low specific weight and high temperature wear resistance, along with low thermal conductivity which has a negative influence on the machining process $[6,7$ and 8].

Commercially pure titanium, unlike titanium alloys, doesn't have the strength required to endure higher force loads and is primarily used for surface coatings and dental implants [9].

The advantage of titanium-based materials is that they are absolutely tasteless and can be a good alternative choice for patients with an allergy or toxic reaction to various dental alloys. Titanium corrosion behaviour is recommended for dental applications [10 and 11]. Moreover, titanium alloys are increasingly used for dental implants these days.

The final chemical composition of nano-structured titanium depends on the initial chemical composition of the titanium at the beginning of the forming process, for example ECAP, where the structure of the formed material is transformed as a result of grain size reduction and thus modification to the mechanical properties. Therefore, these nano-structured materials are characterised by unique mechanical properties that have positive effects on biocompatibility and still maintain the required chemical purity, (Fig. 2) [12, 13 and 14].

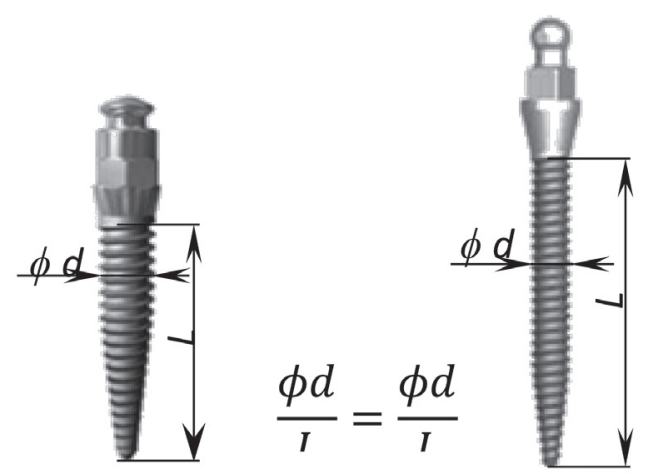

Fig 2 Nano-structured titanium

The most important property is its strength. The strength of nano-structured titanium nTi is 3.6 times greater than the strength indicated in standards for commercially pure titanium cpTiGr 2 . This value is represented by ultimate strength $\mathrm{Rm}$ which is not final and with gradually improving manufacturing technologies the $\mathrm{Rm}$ of $\mathrm{nTi}$ is now almost four times higher than cpTi, as well as having a lower modulus of elasticity. Titanium has the greatest values of $\mathrm{Rm}$ and density in comparison to Ti alloys or Ni-Co-Cr-Mo alloys. The chemical composition corresponds to the quality of $\mathrm{Gr} 4$, containing $99 \%$ titanium and is free from the potential of the organism having an allergic reaction to other elements [15 and 16].

\section{Material and experiment conditions}

Experimental measurements were performed on materials: commercially pure titanium Ti Grade 2 (Fig. 3a), Ti Grade 5 (Fig. $3 c)$ which is considered as an alloy, commercially pure volumeformed titanium (Fig. 3b) and titanium alloy TiNbTa (Fig. 3d) modified by volume-forming technology. The main mechanical properties and hardness are shown in Table 1.
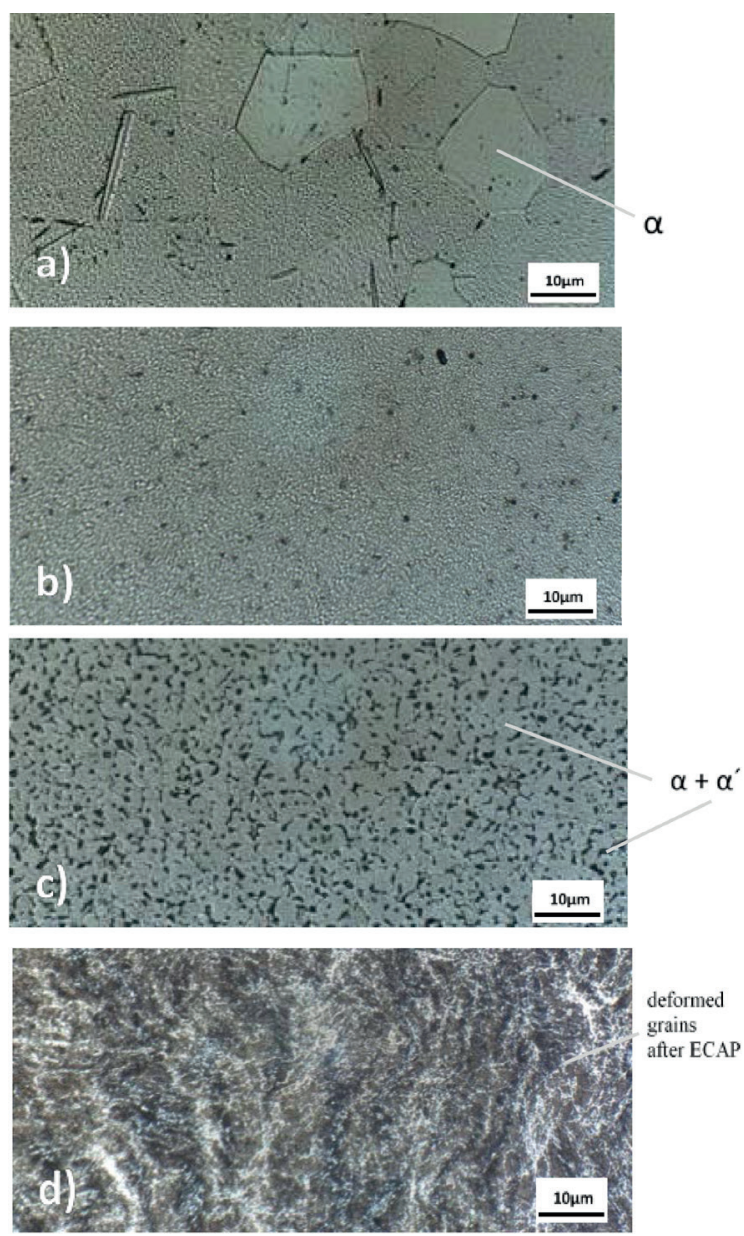

Fig. 3 Microstructure of machined materials: a) nTi, b) TiGr2, c) TiGr5, d) TiNbTa - etch Kroll 
Main mechanical properties and hardness of machined materials

Table 1

\begin{tabular}{|c|c|c|c|c|}
\hline $\begin{array}{c}\text { Machined } \\
\text { material }\end{array}$ & $\mathrm{Rm}(\mathrm{MPa})$ & $\mathrm{Rp}_{0,2}(\mathrm{MPa})$ & $\mathrm{A} 5(\%)$ & $\mathrm{HV} 10$ \\
\hline TiGr2 & $\min .345$ & $275-450$ & 20 & 146 \\
\hline $\mathrm{TiGr} 5$ & $\min .895$ & $\min .828$ & 10 & 314 \\
\hline $\mathrm{nTi}$ & 1240 & 1200 & 12 & 336 \\
\hline TiNbTa & 917 & 859 & 10,9 & 233 \\
\hline
\end{tabular}

Samples were prepared from these materials and then tested on a CNC machining centre HURCO WMX 30t. The experiment was focused on monitoring cutting forces relative to cutting parameters in the milling operation. Cutting conditions were chosen according to functional dependencies: cutting speed $v$ $=20 \div 40 \mathrm{~m} \cdot \mathrm{min}^{-1}$, feed $f_{z}=0.02 \div 0.06$, depth of cut $a_{p}=0.3 \div$ $0.5 \mathrm{~mm}$. In the experiment a monolithic endmill with diameter $4 \mathrm{~mm}$ was used (Fig. 4). This is a sintered carbide milling tool with four cutting edges with TiAlN coating.

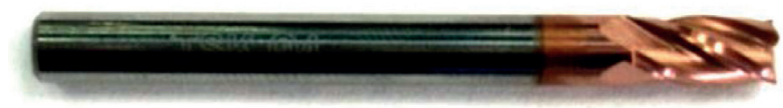

Fig. 4 The monolithic endmill

\section{Experiment}

In milling, the cross-section of the chip varies, which leads to significant modification of the cutting forces during the process. The value of the cutting forces also depends on the number of cutting edges and the sum of the lengths of the cutting edges currently in work. The total force of cutting is the sum of the elemental forces caused by individual cutting edges. The cutting forces caused by the mill-tooth on the machined material can be imagined as two forces (see Fig. 5): tangential force $F$ and radial force $F_{f}$ which points out of the centre of the circle at the location of the largest chip cross-section [13, 17 and 18].

The result of these forces is $F_{A}$ with the same orientation as the vector of main cutting speed $v_{e}$ and is called the active force. If the mill has oblique or helical teeth, there is an additional force $F_{p}$ in the axial direction. The sum of $F_{p}$ and $F_{A}$ results in the total force of cutting $F$ [13 and 19].

To measure the components of cutting forces during milling, as well as the axial force and torque during drilling, a four-component piezoelectric dynamometer KISTLER type 9273 was used.

The values recorded by the dynamometer were subsequently processed using DASY Lab software and used to contruct the graphical dependencies of cutting forces and time which served as the core for the creation of structural equations describing the effect of cutting parameters on cutting force components (Tables 2 and 3).

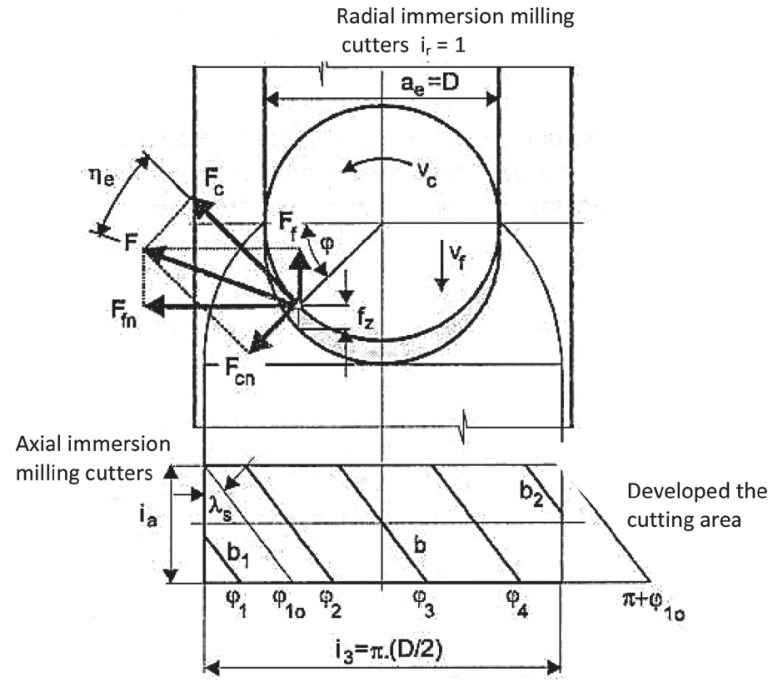

Fig. 5 Decomposition of force of cutting in helical milling [13]

Structural equations of $F_{c}$ and $F_{f}$ determined

from the experiment

Table 2

\begin{tabular}{|c|c|c|}
\hline & $F_{f u}$ & $F_{f}$ \\
\hline$T i G r 2$ & $\mathrm{~F}_{\mathrm{c}}=12.64 \cdot \mathrm{v}_{\mathrm{c}}^{1.28} \cdot \mathrm{f}^{0.9} \cdot \mathrm{a}_{\mathrm{p}}^{0.49}$ & $\mathrm{~F}_{\mathrm{f}}=6.97 \cdot \mathrm{v}_{\mathrm{c}}^{1.4} \cdot \mathrm{f}^{0.62} \cdot \mathrm{a}_{\mathrm{p}}^{1.46}$ \\
\hline $\boldsymbol{R}^{2}$ & 0.89 & 0.88 \\
\hline $\boldsymbol{n} T \boldsymbol{i}$ & $\mathrm{F}_{\mathrm{c}}=1005 \cdot 63 \cdot \mathrm{v}_{\mathrm{c}}^{0.18} \cdot \mathrm{f}^{0.88} \cdot \mathrm{a}_{\mathrm{p}}^{1.07}$ & $\mathrm{~F}_{\mathrm{f}}=1958.75 \cdot \mathrm{v}_{\mathrm{c}}^{0.28} \cdot \mathrm{f}^{0.76} \cdot \mathrm{a}_{\mathrm{p}}^{1.24}$ \\
\hline $\boldsymbol{R}^{2}$ & 0.96 & 0.92 \\
\hline TiGr5 & $\mathrm{F}_{\mathrm{c}}=795.32 \cdot \mathrm{v}_{\mathrm{c}}^{0.17} \cdot \mathrm{f}^{0.94} \cdot \mathrm{a}_{\mathrm{p}}^{0.84}$ & $\mathrm{~F}_{\mathrm{f}}=74.74 \cdot \mathrm{v}_{\mathrm{c}}^{0.64} \cdot \mathrm{f}^{0.88} \cdot \mathrm{a}_{\mathrm{p}}^{0.91}$ \\
\hline $\boldsymbol{R}^{2}$ & 0.94 & 0.92 \\
\hline TiNbTa & $\mathrm{F}_{\mathrm{c}}=127.33 \cdot \mathrm{v}_{\mathrm{c}}^{0.82} \cdot \mathrm{f}^{1.03} \cdot \mathrm{a}_{\mathrm{p}}^{0.95}$ & $\mathrm{~F}_{\mathrm{f}}=175.30 \cdot \mathrm{v}_{\mathrm{c}}^{0.28} \cdot \mathrm{f}^{0.57} \cdot \mathrm{a}_{\mathrm{p}}^{1.36}$ \\
\hline $\boldsymbol{R}^{2}$ & 0.91 & 0.9 \\
\hline
\end{tabular}

Structural equations of $F_{p}$ and $F$ determined

from the experiment

Table 3

\begin{tabular}{|c|c|c|}
\hline & $F_{p}$ & $F$ \\
\hline TiGr2 & $\mathrm{F}_{\mathrm{p}}=1.05 \cdot \mathrm{v}_{\mathrm{c}}^{1.95} \cdot \mathrm{f}^{1.1} \cdot \mathrm{a}_{\mathrm{p}}^{0.94}$ & $\mathrm{~F}=14.85 \cdot \mathrm{v}_{\mathrm{c}}^{1.34} \cdot \mathrm{f}^{0.84} \cdot \mathrm{a}_{\mathrm{p}}^{0.77}$ \\
\hline $\boldsymbol{R}^{2}$ & 0.9 & 0.87 \\
\hline $\boldsymbol{n} T \boldsymbol{i}$ & $\mathrm{F}_{\mathrm{p}}=178.25 \cdot \mathrm{v}_{\mathrm{c}}^{0.28} \cdot \mathrm{f}^{0.77} \cdot \mathrm{a}_{\mathrm{p}}^{1.46}$ & $\mathrm{~F}=1498.75 \cdot \mathrm{v}_{\mathrm{c}}^{0.09} \cdot \mathrm{f}^{0.85} \cdot \mathrm{a}_{\mathrm{p}}^{1.1}$ \\
\hline $\boldsymbol{R}^{2}$ & 0.93 & 0.97 \\
\hline$T i G r 5$ & $\mathrm{~F}_{\mathrm{p}}=2114.31 \cdot \mathrm{v}_{\mathrm{c}}{ }^{0.11} \cdot \mathrm{f}^{1.14} \cdot \mathrm{a}_{\mathrm{p}}^{1.41}$ & $\mathrm{~F}=738.09 \cdot \mathrm{v}_{\mathrm{c}}^{0.28} \cdot \mathrm{f}^{0.94} \cdot \mathrm{a}_{\mathrm{p}}^{0.93}$ \\
\hline $\boldsymbol{R}^{2}$ & 0.92 & 0.97 \\
\hline TiNbTa & $\mathrm{F}_{\mathrm{p}}=8.47 \cdot \mathrm{v}_{\mathrm{c}}{ }^{1.27} \cdot \mathrm{f}^{0.93} \cdot \mathrm{a}_{\mathrm{p}}^{1.8}$ & $\mathrm{~F}=191.39 \cdot \mathrm{v}_{\mathrm{c}}^{0.63} \cdot \mathrm{f}^{0.88} \cdot \mathrm{a}_{\mathrm{p}}^{1.04}$ \\
\hline $\boldsymbol{R}^{2}$ & 0.87 & 0.95 \\
\hline
\end{tabular}

The structural equations formed a core for the creation of a complete 3D visual display of four-dimensional functionality (Figs. 6 - 9).

From the output values of the total force of cutting $F$, it can be stated that the lowest values of total static force $F$ were 
achieved with titanium alloy TiNbTa, and the highest values were achieved with nano-structured titanium Grade 4. From the results it can be observed that with the chosen moderate cutting speed $v_{c}=30 \mathrm{~m} \cdot \mathrm{min}^{-1}$, moderate feed $f_{z}=0.04 \mathrm{~mm}$ and low cutting depth $a_{p}=0.1 \mathrm{~mm}$ the lowest values of total static and dynamic force of cutting $F$ can be achieved. With the chosen moderate cutting speed $v_{c}=30 \mathrm{~m} \cdot \mathrm{min}^{-1}$, moderate feed $f_{z}=0.04 \mathrm{~mm}$ and high cutting
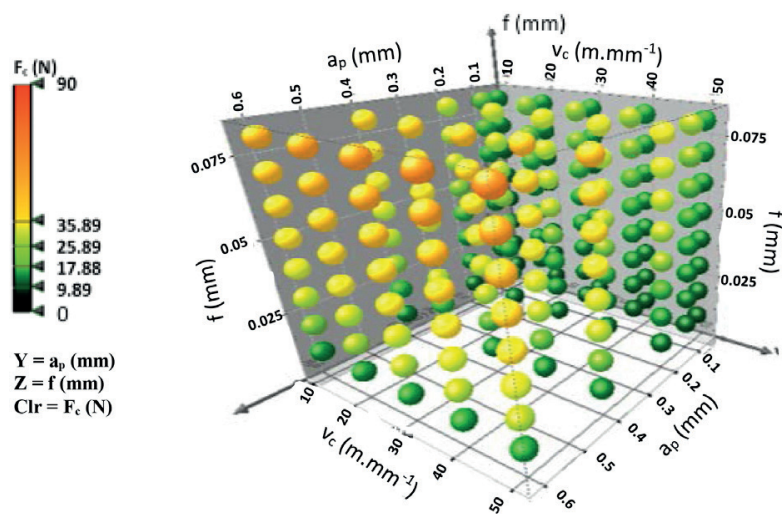

Fig. 6 Cutting force component when applying estimated cutting parameters for TiGr2

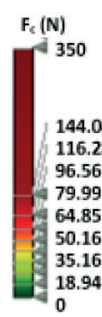

$\mathbf{Y}=\mathbf{a}_{\mathrm{p}}(\mathrm{mm})$ $\mathrm{Z}=\mathbf{f}(\mathrm{mm})$ $\mathrm{Cl} \mathbf{r}=\mathbf{F}_{\mathrm{c}}(\mathbf{N})$

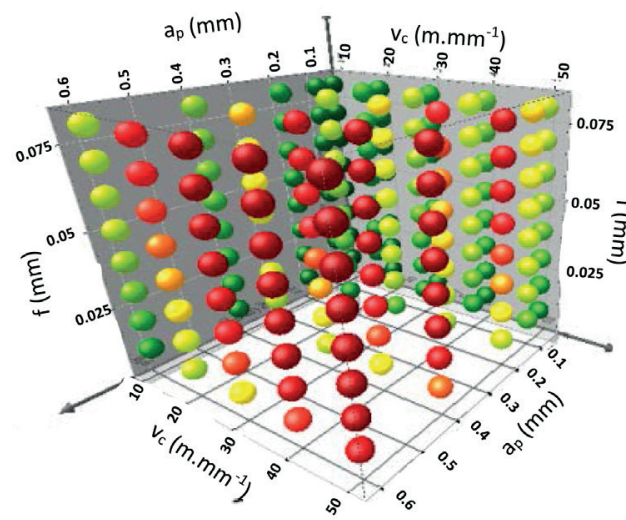

Fig. 7 Cutting force component when applying estimated cutting parameters for $n T i$
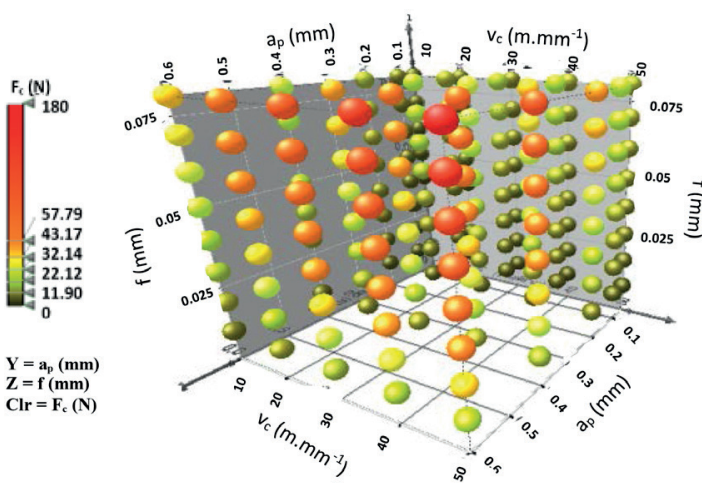

Fig. 8 Cutting force component when applying estimated cutting parameters for $T i G r 5$ depth $a_{p}=0.5 \mathrm{~mm}$ the highest values of total static and dynamic force of cutting $F$ can be achieved.
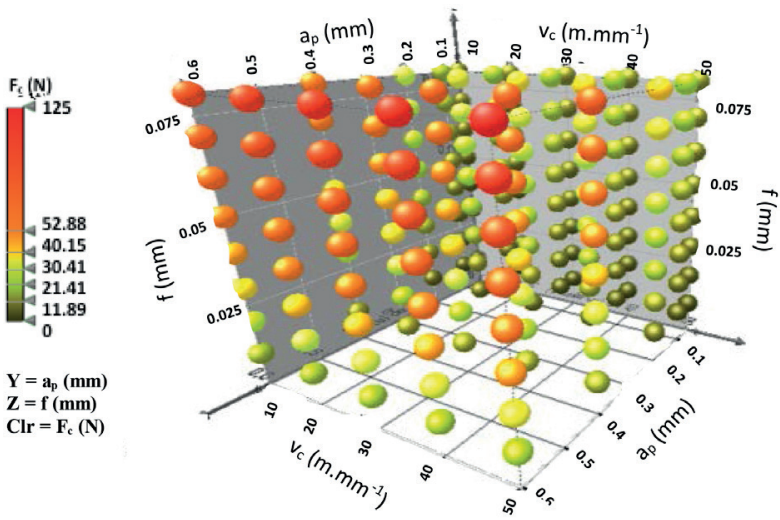

Fig. 9 Cutting force component when applying estimated cutting parameters for TiNbTa

\section{Conclusion}

Based on the analysed results of experimental tests performed on these titanium materials, technically pure titanium and its alloys behave very differently in the cutting process compared to conventional metallic materials.

The main task of the experiment was to obtain information from the machining process about the behaviour of new materials introduced into the field of dental medicine for the production of extremely thin dental implants, with emphasis on their practical use. The experiment aimed to examine the dynamic power ratios and measuring components of cutting force during milling, especially where static variables were monitored.

The facts referred to in this article provide valuable knowledge of machining titanium and titanium alloys, which can contribute to the choice of the appropriate cutting conditions for machining these materials, considering the process intensification. The correct choice of cutting conditions may reduce the static and dynamic load of the machine-tool-workpiece-jig system, and thereby it is possible to increase the performance and operational characteristics of the products and to reduce production costs. These results serve as a support for solving problems in the manufacturing of dental implants as well as in other industries using titanium-based biomaterials.

\section{Acknowledgement}

The article was funded by the University of Zilina project OPVaV-2009/2.2/04-SORO number (26220220101) - "Intelligent system for nondestructive technologies on evaluation for the functional properties of components of X-ray diffraction" and grant project VEGA 1/0773/12 - "Implementation of technical ceramic material research to increase the innovation of hybrid products". 


\section{References}

[1] CZAN, A., STANCEKOVA, D., MRAZOVA, M., SEMCER, J.: Conditions of Hardmachining Materials Machinability usable in Biomedicine, Intern. working conference: Total Quality Management - Advanced and Intelli-Genapproaches, with Second Special Conference: Manufuture in Serbia 2011, ISBN 978-86-7083-727-0

[2] SEMCER, J., MRAZOVA, M., PILC, J.: Biocompatible Materials and their Ways of Machinin, Technological Engineering, 2010, 45-46, ISSN 1336-5967

[3] TVRDON, M. et al.: Prosthetic Stomatologia (in Slovak), Bratislava : Svornost, 2006, 581 p., ISBN 80-969524-4-7

[4] SELINGEROVA, S.: Development of dental implants (in Czech), Bachelor thesis, VUT Brno : Fakulta strojniho inzenyrstvi : Ustav mechaniky telies mechatroniky a biomechaniky, 2009

[5] SIMUNEK, A. et al.: Dental Implantolog (in Czech), Hradec Kralove: Stomatologicka klinika FN a LFUK, 2008,296 p., ISBN 978-80-87009-30-9

[6] CZAN, A., TILlOVA, E., SEMCER, J., PILC, J.: Surface and Subsurface Residual Stresses after Machining and their Analysis by x-ray Diffraction, Communications - Scientific Letters of the University of Zilina, No. 2, 69-76, 2013, ISSN 1335-4205

[7] CEP, R., JANASEK A., PETRU J., CEPOVA L., CZAN A., VALICEK J.: Hard Machinable Machining of Cobalt-based Superalloy, Manufacturing Technology, XIII/13, 2013, 226-231, UJEP : Usti n. Labem, ISSN 1213-2489

[8] NAPRSTKOVA, N., HOLESOVSKY, F.: Admeasurement of Grinding Wheel Loss at FPTM, 24 ${ }^{\text {th }}$ intern. colloquium Advanced manufacturing and repair technologies in vehicle industry, 2007, 159-164, ISBN 978-80-7194-962-6.

[9] HOLESOVSKY, F., NAPRSTKOVA, N., NOVAK, M.: GICS for Grinding Process Optimization. Manufacturing Technology, XII/12, 2012, 22-26, UJEP: Usti n. Labem, ISSN 1213-2489.

[11] SKUBLOVA, L., SKORIK, V., MRAZIKOVA, R., HADZIMA, B: Corrosion Resistance of Ti6al4v Titanium Alloy with Modified Surfaces. Communications - Scientific Letters of the University of Zilina, No. 4, 2010, 80-84, ISSN 1335-4205

[12] CEP, R., JANASEK, A., CEPOVA, L., PETRU, J., HLAVATY, I., CAR, Z., HATALA, M.: Experimental Testing of Exchangeable Cutting Inserts Cutting Ability. Tehnicki Vjesnik, 20 (1), 2013, 21-26, ISSN: 1330-3651

[13] NOVAKOVA, J., PETRKOVSKA, L., BRYCHTA, J., STANCEKOVA, D.: Influence of Cutting Parameters on Integrity Surface at High Speed Cutting. Transactions of the VSB - Technical University of Ostrava. Mechanical Series, vol. LV, No. 1, 2009, 203 209, Ostrava: VSB - TUO

[14] SAPIETOVA, A., SAGA, M., NOVAK, P.: Multi-software Platform for Solving of Multibody Systems Synthesis, Communications - Scientific Letters of the University of Zilina, vol. 14, No. 3, 43-48, 2012, ISSN 1335-4205

[15] LiTVAJ, I., PONISCIAKOVA, O., STANCEKOVA, D., DRBUL, M.: Knowledge Processes and their Implementation in Small Transport Companies, $17^{\text {th }}$ intern. conference Transport Means 2013, Kaunas, October 2013, Code 102486, 153-156, ISSN: $1822-$ 296X

[16] CZAN, A., SAJGALIK, M., HOLUBJAK, J., KOURIL, K.: Studying of Cutting Zone when Finishing Titanium Alloy by Application of Multifunction Measuring System, Manufacturing Technology, vol. 13, No. 4, December 2013, 428-431, ISSN: 12132489

[17] PILC, J., MICIETOVA, A., SALAJ, J., CILLIKOVA, M.: The Influence of the Selected Aspects in Planing Operations by using Auto-rotation Tool, Transactions of Famena, vol. 29, No. 2, 2005, 55-60, ISSN: 1333-1124

[18] VASILKO, K., PILC, J.: New Technological Knowledge of the Rotary Turning Tool, J. Manufacturing Technology, vol. 13, No. 4, December 2013, 571-575, ISSN: 1213-2489

[19] KRAJCOVIC, M., BULEJ, V., SAPIETOVA, A., KURIC, I.: Intelligent Manufacturing Systems in Concept of Digital Factory. Communications - Scientific Letters of the University of Zilina, No. 2, 2012, ISSN 1335-4205

[20] CUBONOVA , N.: Post-processing of CL Data in CAD/CAM System Edgecam using the Constructor of Post-processors, Manufacturing Technology : J. for Science, Research and Production, vol. 13, No. 2, 2013, 158-164, ISSN 1213-2489. 